\title{
The Influence of Jigsaw Using Kahoot Assessment on Interest and Learning Outcomes
}

\author{
Risma Uly Manalu*, and Jonatan \\ Department of Mathematics Education, Universitas Kristen Indonesia, Jakarta, Indonesia \\ Corresponding Email: rismauly@gmail.com
}

\begin{abstract}
The purpose of this study is to determine whether there is an influence by implementing the Jigsaw Type Cooperative Learning Model towards the interests and learning outcomes of the volume of geometrical building material for students of 50 Junior High School in the East Jakarta. (1) the research approach used is quantitative research, (2) the type of research used is quasi-experimental, (3) the same population and sample are 64 students from grades VIII-B and VIII$\mathrm{D}$ in 50 Junior High School in the East Jakarta, (4) the analysis technique used is the t-test it can be seen that there is an influence between students who are taught by using a jigsaw cooperative learning model using kahoot assessment with a conventional learning model, with a value of $t=6.402>t$ table $=1.696$ at a significant level of $5 \%$. Thus it can be concluded that there is a positive influence on the type of jigsaw cooperative learning model on the interests and learning outcomes of students from class VIII in 50 Junior High School in the East Jakarta. The magnitude of the effect of the jigsaw cooperative learning model using kahoot assessment on the interests and learning outcomes of eighth grade students of 50 Junior High School in the East Jakarta was $11.37 \%$.
\end{abstract}

Keywords: Jigsaw, Kahoot Assessment, Learning Interest, Learning Outcomes, Mathematics, Space Build Volumes

\section{INTRODUCTION}

In general, many people are afraid of learning mathematics on the grounds that mathematics is difficult (Purnami et al., 2018; Widodo et al., 2019, 2017). Mathematical reasoning is considered difficult, it is seen from the abstract nature of mathematics that causes many students have difficulty in understanding various concepts (Adi Widodo et al., 2018; Fitriyani et al., 2018; Widodo, 2018), in answering the questions given are still monotonous, not varied so that students become not excited (Kusuma et al., 2017). There are still many students who think that mathematics is a difficult subject to understand, due to the following: (1) memorization of formulas, (2) counting, (3) less interesting in the delivery of learning systems, (4) and the use of limited learning media (Brush et al., 1999; Mizala et al., 2015; Peker, 2009; Sheldon and Epstein, 2005).

At present there are several active, creative and interesting learning media used in learning (Adi Widodo et al., 2018; Aryuntini et al., 2019; Liberatore et al., 2018; Reiser and Gagne, 1982; Saputro, 2016; Thomas and Akdere, 2013; Widodo, 2018; Widodo et al., 2018). One of the interesting and information technology-based learning media is kahoot (Chaiyo and Nokham, 2017; Dellos, 2015; Lin et al., 2018; Plump and LaRosa, 2017; Wang and Lieberoth, 2016). Kahoot is an online application for making quizzes and surveys interactively (Basuki and Hidayati, 2019; Kuo and Chuang, 2018; Pede and Accardo, 2017; Yap1c1 and Karakoyun, 2017)

The objectives to be achieved in this study are (1) determine the effect of the Jigsaw cooperative learning model using kahoot assessments on mathematics learning interest, and (2) knowing the effect of the Jigsaw cooperative learning model using kahoot assessment on mathematics learning outcomes.

\section{METHOD}

This research was conducted at SMPN 50 East Jakarta with the aim to determine the effect of the jigsaw cooperative method using kahoot assessment in 
increasing interest and learning outcomes in the even semester 2018/2019.

The research design and research design used in this research data are Pre-Test Post-test Control design group. This design can be described as in table 1 .

Table 1 Research Design

\begin{tabular}{|c|c|c|c|}
\hline Class & Pretest & Treatment & Posttest \\
\hline Experiment & $T_{1 E}$ & Suitcase type jigsaw & $T_{2 E}$ \\
\hline Control & $T_{1 K}$ & Conventional & $T_{2 K}$ \\
\hline
\end{tabular}

Before the test is given to the control class and the experimental class the test needs to be tested for its validity and reliability. "Said that a test data with content validity testing can be done by comparing the contents of the instrument with the subject matter that has been taught".

So that the research used validity testing in the form of expert validity, namely: supervisor I, supervisor II and class VIII 50 State Junior High School Jakarta. The purpose of data analysis is to test or answer the truth of the proposed hypothesis. To test the research hypothesis the following steps are used: Normality Test, Homogeneity Test, and Hypothesis Test. The data management stage after the data is ready, then the next step is to analyze the research data and test the hypothesis.

\section{RESULT AND DISCUSSION}

\subsection{Learning Outcomes Test}

So in this study student learning outcomes in the control class in the pretest-posttest score was 44.84 to 67.34 , the control class increased by 22.5 . While in the experimental class the pretest-posttest value also increased significantly by 26.72 with a value of 47.81 to 74.53 . For the questionnaire test results obtained lower student responses in the control class compared to the experimental class, which is 65.93 residual responses in the control class and 70.81 student responses in the experimental class.

\subsection{Descriptive Statistics}

Descriptive Statistics of Questionnaire Data Conventional Pre-test Descriptive Statistic.

Table 2. Interest in Learning Control Class

\begin{tabular}{llllll}
\hline Max & Min & Mean & Median & Mode & Std \\
\hline 72 & 57 & 65,93 & 68,5 & 62,77 & 3,917 \\
\hline
\end{tabular}

Based on the analysis and description of the data obtained a mean of 65.98 , SD (standard deviation) of 3.917 median 68.5 and mode 62.77. And the number of interval classes is determined by the formula $\mathrm{K}=1+$ $3.3 \log 32$ the result is 5.983. The range of data (70-57) $=13$, while the length of the class that I got from the range divided by the number $(13 / 6=2.1)$.

\subsection{Post-test Descriptive Statistics of Experiments Using a Jigsaw}

Table 3. Interest in Learning Experimental Class

\begin{tabular}{llllll}
\hline Max & Min & Mean & Median & Mode & Std \\
\hline 77 & 62 & 70,82 & 70,3 & 69,9 & 3,115 \\
\hline
\end{tabular}

Learning interest data obtained from the questionnaire data processing results that have been filled out by the experimental group, namely students of class VIII-D at SMPN 50 East Jakarta. Based on the analysis and description of the data obtained a mean of $70.817, \mathrm{SD}$ (standard deviation) of 3.115 , a median of 69.9 and a mode of 69.99 . And the number of interval classes is determined by the formula $\mathrm{K}=1+3.3 \log 32$ the result is 5.983 rounded up to 6 . Data range 77-62 = 15 , while the length of the class that I got from the range.

\subsection{Descriptive Statistics of Learning Outcomes}

Descriptive Statistics of Pre-Test Control Class.

Table 4. Control Class Learning Outcomes

\begin{tabular}{cccccc}
\hline Max & Min & Mean & Median & Mode & Std \\
\hline 75 & 15 & 44,84 & 50,21 & 45 & 1,482 \\
\hline
\end{tabular}

Based on the analysis and description of the data, obtained the mean results of 44.84 rounded up to 45 , SD (standard deviation) of 17.482, median 50.21 and mode 45. And the number of interval classes is determined by the formula $\mathrm{K}=1+3.3 \log 32$ the result is 5,967 rounded to 6 . The range of data $(75-15=60)$, while the length of the class that I got from the range divided by the number $(60 / 6=10)$ the result is 10 . Descriptive Pre-test Experimental Statistics

Table 5. Experimental Class Learning Outcomes

\begin{tabular}{cccccc}
\hline Max & Min & Mean & Median & Mode & Std \\
\hline 85 & 15 & 47,81 & 50 & 60 & 19,42 \\
\hline
\end{tabular}

Based on the analysis and description of the data obtained the mean result of 47.81, SD (standard 
deviation) of 19.424 , median 50 and mode 60, and the number of interval classes is determined by the formula $\mathrm{K}=1+3.3 \log 32$ the result is 5.967 rounded up to 6 . The range of data is $85-15=70$, while the length of the class that I got from the range divided by the number $(70 / 6=11.7)$ the result is 12 .

\subsection{Descriptive Statistics of Post-test Control Class}

Table 6. Control Class Post-Test Learning Outcomes

\begin{tabular}{cccccc}
\hline Max & Min & Mean & Median & Mode & Std \\
\hline 95 & 35 & 67,34 & 65 & 65 & 13,559 \\
\hline
\end{tabular}

Based on the analysis and description of the data obtained the mean result of 47.81, SD (standard deviation) of 19.424 , median 50 and mode 60 , and the number of interval classes is determined by the formula $\mathrm{K}=1+3.3 \log 32$ the result is 5.967 rounded up to 6 . The range of data is $85-15=70$, while the length of the class that I got from the range divided by the number $(70 / 6=11.7)$ the result is 12 .

\subsection{Descriptive Statistics of Post-test Experiments}

Table 7. Control Class Learning Outcomes

\begin{tabular}{cccccc}
\hline $\begin{array}{c}\text { Max } \\
\text { Valu } \\
\mathrm{e}\end{array}$ & $\begin{array}{c}\text { Min } \\
\text { Valu } \\
\mathrm{e}\end{array}$ & $\begin{array}{c}\text { Mea } \\
\mathrm{n}\end{array}$ & $\begin{array}{c}\text { Media } \\
\mathrm{n}\end{array}$ & $\begin{array}{c}\text { Mod } \\
\mathrm{e}\end{array}$ & Std \\
\hline 100 & 40 & $\begin{array}{c}74,5 \\
3\end{array}$ & 75 & 65 & $\begin{array}{c}12,13 \\
9\end{array}$ \\
\hline
\end{tabular}

Based on the analysis and description obtained the mean result of $74.53 \mathrm{SD}$ (standard deviation) of rounded to 12.139 , median 75 and mode 65 . And the number of interval classes is determined by the formula $\mathrm{K}=1+3.3 \log 32$ the result is 5.967 rounded to 6 . The data range is $100-40=60$, while the length of the class that I got from the range is divided by the number $60 / 6$ $=10$.

\section{DISCUSSION}

Based on a purposive sampling technique the study determines the available classes without random sampling, meaning that the deliberate sampling of the control class that gets conventional learning and the experimental class gets the jigsaw cooperative learning method using kahoot assessment. From the results of the study were processed using statistical tests. Where the results of the data that have been processed get the results obtained for the experimental class the lowest score of 15 prettest and the highest score of 75 with an average of 47.81. While the lowest experimental posttest score was 40 and the highest was 100 with an average of 74.53 . At prettest $87.3 \%$ did not complete or did not reach the KKM because they did not understand the material, after being given treatment in the experimental class $74.53 \%$ of students completed or reached the KKM. Because it has been given treatment.

Whereas in the control class from the known data results the lowest pret-test value is 15 and the highest value is 75 with an average of 44.84 . While the posttest scores in the control class were 35 and the highest 95 with an average of 67.34. In the dick class pretest $90.42 \%$ did not complete or did not reach the KKM. Because it hasn't been studied by students. While the control class posttest 37.42 students completed or achieved the KKM value. Lack of student interest in learning and answering questions about the control class posttest and causing a decrease in posttest results of students in the control class because learning is only one way or only the teacher is more active in learning while students listen more and not only reciprocity between students and teachers. To find out how much influence the results of student mathematics learning are done t-test. The results of the t-test in that class amounted to 2.234 by entering the medium class category. Because the questions given are still said to be easy and the number of questions is small.

The learning process in the experimental class gets teaching and learning activities based on the application of the jigsaw cooperative learning model, the results of research with the learning process can be carried out well during the learning activities the research activities are carried out for 5 meetings, where the learning process is carried out 3 times. In the first stage, the researcher divided the groups, each group consisting of 4 people and each group had a leader and the chairman as an expert to codify as well as teach his friends who did not understand. In the next learning meeting the researcher delivered the material along with the questions using Kahoot Application media where the kahoot application media was assisted by LCD and the internet network helped the researcher to convey the questions and each group was told to have the cellphone of the group in order to be able to answer questions. This kahoot application not only conveys but also gives a score for each group's answers. Where every student looks enthusiastic in participating in the learning presentation, conducive, and interest in participating in learning increases.

In the control class applied conventional learning modes namely meaningful lectures and questions and answers. The learning process in the control class takes place in 3 days where one day is face to face for 70 minutes. The application of the lecture model provides 
more opportunities for teachers to take roles during the learning process, so that student activity is reduced. Students only accept what is conveyed by the teacher with little response, both in the form of questions and responses from students.

The results of the study and observation indicated that some control class students had the same attractiveness and enthusiasm in learning with the experimental class during the learning process. However, most of the others show the opposite results. That is lower than the experimental class because many control students did not respond or respond to the material even though the students did not understand but were not asked so that the achievement was less satisfying.

Many things are obtained when carrying out research jigsa type cooperative methods using kahoot assessment one of which is a constraint, namely the internet network is not strong enough, LCD error. The results of research and observations that have been made, the type of jigsaw cooperative method using kahoot assessment is very helpful in learning so that learning can attract students' attention in learning. The Jigsaw type cooperative method is suitable for use in the teaching-learning process so that the Jigsaw type cooperative method can increase the interest and learning outcomes of students of class VIII at SMP Negeri 50 East Jakarta, the material for building volume. which means that there is an influence of the jigsaw cooperative method on learning outcomes. Based on the above analysis, there are differences between students taught using the Jigsaw cooperative learning model and students who learn conventional learning.

\section{CONCLUSION}

Based on the results of research on the Jigsaw type cooperative learning model on the interests and learning outcomes of students of class VIII SMP Negeri 50 East Jakarta, it can be concluded as follows:

a. The influence of differences in learning interest between students who are taught by using the Jigsaw type cooperative learning model using grade VIII student kahoot assessment in East Jakarta 50 Public Schools. this is indicated for the results of the questionnaire data there are differences in student responses between the control class and the experimental class where the value of the experimental questionnaire results is higher than the control results where 70.81 are experimental results and 65.93 results of student questionnaire responses in the control class.

b. The influence of differences in learning outcomes between students taught using the Jigsaw cooperative learning model using grade VIII student's kahoot assessment in East Jakarta 50 Public Schools. this is shown t count (2.234) is greater than $t$ table (1.669) at a significance level of 0.000 less than 0.05 .

\section{REFERENCES}

1. Adi Widodo, S., Turmudi, T., Afgani Dahlan, J., Istiqomah, I., Saputro, H., 2018. Mathematical Comic Media for Problem Solving Skills, in: International Conference on Advance \& Scientific Innovation. pp. 101-108.

2. Aryuntini, N., Astuti, I., Yuliana, Y.G.S., 2019. Development of Learning Media Based on VideoScribe to Improve Writing Skill for Descriptive Text of English Language Study. JETL (Journal Educ. Teach. Learn. 3, 187.

3. Basuki, Y., Hidayati, Y., 2019. Kahoot! or Quizizz: the Students' Perspectives. https://doi.org/10.4108/eai.27-4-2019.2285331

4. Brush, T.A., Armstrong, J., Barbrow, D., Ulintz, L., 1999. Design and delivery of integrated learning systems: Their impact on student achievement and attitudes. J. Educ. Comput. Res. https://doi.org/10.2190/PTPT-NN3H-4C208NYE

5. Chaiyo, Y., Nokham, R., 2017. The effect of Kahoot, Quizizz and Google Forms on the student's perception in the classrooms response system, in: 2nd Joint International Conference on Digital Arts, Media and Technology 2017: Digital Economy for Sustainable Growth, ICDAMT 2017. https://doi.org/10.1109/ICDAMT.2017.7904957

6. Dellos, R., 2015. Kahoot! A digital game resource for learning. Int. J. Instr. Technol. Distance Learn.

7. Fitriyani, H., Widodo, S.A., Hendroanto, A., 2018. STUDENTS , GEOMETRIC THINKING BASED ON VAN HIELE' S THEORY. Infin. J. 7, https://doi.org/10.22460/infinity.v7i1.p55-60

8. Kuo, C.L., Chuang, Y.H., 2018. Kahoot: Applications and effects in education. J. Nurs. https://doi.org/10.6224/JN.201812_65(6).03

9. Kusuma, I.P.I., Adnyani, N.L.D.S., Taharyanti, G.A.P., 2017. Developing 10 Interesting Games as the Breakthrough of Monotonous Implementation of Flashcards to Vocabulary Learning and Assessments. Scr. J. J. Linguist. English Teach. 
https://doi.org/10.24903/sj.v2i1.65

10. Liberatore, A., Bowkett, E., Macleod, C.J., Spurr, E., Longnecker, N., 2018. Social Media as a Platform for a Citizen Science Community of Practice. Citiz. Sci. Theory Pract. 3, 1-14.

11. Lin, D.T.A., Ganapathy, M., Kaur, M., 2018. Kahoot! It: Gamification in higher education. Pertanika J. Soc. Sci. Humanit.

12. Mizala, A., Martínez, F., Martínez, S., 2015. Preservice elementary school teachers' expectations about student performance: How their beliefs are affected by their mathematics anxiety and student's gender. Teach. Teach. Educ. https://doi.org/10.1016/j.tate.2015.04.006

13. Pede, J., Accardo, A., 2017. The Effects of the Online Game Kahoot on Science Vocabulary Acquisition. ProQuest Diss. Theses.

14. Peker, M., 2009. Pre-service teachers' teaching anxiety about mathematics and their learning styles. Eurasia J. Math. Sci. Technol. Educ. https://doi.org/10.12973/ejmste/75284

15. Plump, C.M., LaRosa, J., 2017. Using Kahoot! in the Classroom to Create Engagement and Active Learning: A Game-Based Technology Solution for eLearning Novices. Manag. Teach. Rev. https://doi.org/10.1177/2379298116689783

16. Purnami, A.S.A.S., Widodo, S.A.S.A., Prahmana, R.C.I.R.C.I., 2018. The Effect of Team Accelerated Instruction on Students' Mathematics Achievement And Learning Motivation. J. Phys. Conf. Ser. 948, 1-5. https://doi.org/10.1088/17426596/948/1/012020

17. Reiser, R.A., Gagne, R.M., 1982. Characteristics of Media Selection Models. Rev. Educ. Res. 52, 499-512.

18. Saputro, B.A., 2016. Learning Media Development Approach with A Rectangle Problem Posing Based Geogebra. Infin. J. Math. Educ. 6, 121-130.

19. Sheldon, S.B., Epstein, J.L., 2005. Involvement Counts: Family and Community Partnerships and Mathematics Achievement. J. Educ. Res. https://doi.org/10.3200/JOER.98.4.196-207

20. Thomas, K.J., Akdere, M., 2013. Social Media as Collaborative Media in Workplace Learning. Hum. Resour. Dev. Rev. 12, 329-344. https://doi.org/10.1177/1534484312472331

21. Wang, A.I., Lieberoth, A., 2016. The effect of points and audio on concentration, engagement, enjoyment, learning, motivation, and classroom dynamics using kahoot!, in: Proceedings of the European Conference on Games-Based Learning.

22. Widodo, S.A., 2018. Selection of Learning Media Mathematics for Junior School Students. Turkish
Online J. Educ. Technol. - TOJET 17, 154-160.

23. Widodo, S.A., Darhim, Ikhwanudin, T., 2018. Improving mathematical problem solving skills through visual media Improving mathematical problem solving skills through visual media. J. Phys. Conf. Ser. 948, 1-6.

24. Widodo, S.A., Prahmana, R.C.I., Purnami, A.S., Turmudi, 2017. Teaching materials of algebraic equation. J. Phys. Conf. Ser. 943, 1-6.

25. Widodo, S.A., Turmudi, Dahlan, J.A., 2019. An Error Students In Mathematical Problems Solves Based On Cognitive Development. Int. J. Sci. Technol. Res. 8, 433-439.

26. Yapıc1, İ.Ü., Karakoyun, F., 2017. Gamification in Biology Teaching: A Sample of Kahoot Application. Turkish Online J. Qual. Inq. https://doi.org/10.17569/tojqi.335956 